\title{
HUBUNGAN HARMONIS ANTARA SAINS DAN AGAMA DALAM PEMIKIRAN AL-FARABI DAN IKHWAN AL-SHAFA
}

\author{
Humaidi \\ Sekolah Tinggi Filsafat Islam (STFI) Sadra \\ Jl. Lebak Bulus II No. 2 Cilandak, Jakarta Selatan \\ Email: humaidias97@gmail.com
}

Abstract: The Harmonious Relationship between Science and Religion in the Thought of Al-Farabi and Ikhwan Al-Shafa. Science in the modern view always separate from religion. Science is considered as the only one as scientific things, while religion is non-scientific. The implication of this view is the emergence of a disintegrative understanding, namely the separation between religion and science. Meanwhile, in the Islamic scientific tradition, since birth, grow and development, it has always been based on harmonious relationships among various fields of science including between science and religion. Both of them explain one reality in a different way. This research explains the harmonious relationship between science and religion within the framework of al-Farabi and Ikhwan al-Shafa that grew and developed around the 10th century AD. The thought of al-Farabi and Ikhwan al-Shafa proves that the development of science is always in line with religion, because both come from one source; Almighty God.

Keywords: science, religion, metaphysic, physic, and ethic

Abstrak: $\quad H u b u n g a n$ Harmonis Antara Sains dan Agama Dalam Pemikiran AlFarabi dan Ikhwan Al-Shafa. Sains dalam pandangan modern selalu terpisah dengan agama. Sains sebagai satu-satunya ilmu yang ilmiah, sedangkan agama non-ilmiah. implikasi dari pandangan tersebut adalah munculnya pemahaman yang disintegratif, yaitu pemisahan antara agama dan sain. Penelitian ini menjelaskan tentang hubungan harmonis antara sains dan agama dalam kerangka pemikiran al-Farabi dan Ikhwan al-Shafa yang tumbuh dan berkembang pada sekitar abad ke-10 masehi. Pemikiran al-Farabi dan Ikhwan al-Shafa membuktikan bahwa perkembangan ilmu pengetahuan selalu sejalan dengan agama, karena keduanya berasal dari sumber yang satu, yaitu Tuhan Yang Maha Esa.

Kata Kunci: sains, agama, metafisika, fisika, etika 


\section{Pendahuluan}

Muhammad Taqi Misbah Yazdi dalam bukunya Philosophical Instruction: An Introduction to Contemporary Islamic Pilosophy, menyebutkan bahwa ilmu mempunyai beberapa makna teknis, dan di antara yang paling penting adalah sebagai berikut: Pertama, ilmu adalah keyakinan yang sesuai dengan kenyataan. Kedua, ilmu adalah himpunan proposisi yang dianggap berhubungan satu sama lain, meskipun sifat proposisi-proposisi itu bersifat personal dan tidak spesifik. Dalam pengertian inilah, ilmu diterapkan pada ilmu sejarah, geografi, ilmu rijal, dan biografi. Ketiga, ilmu adalah himpunan proposisi-proposisi hakiki yang bisa dibuktikan dengan pengalaman inderawi, yang mana ruang lingkup pengetahuan hakiki dan pasti manusia hanya terbatas pada hal ihwal yang dapat diindera dan empiris. ${ }^{1}$

Para saintis modern, khususnya empirisme dan positivisme, membatasi penggunaan sains hanya pada pengertian yang ketiga. Bagi mereka tindak berfikir yang melampaui batasan dan ruang lingkup tersebut dianggap tidak bermakna dan tidak berguna. Stephen Hawking misalnya, dalam wawancaranya pada Senin, 16 Mei 2011, dengan The Guardian menyatakan bahwa konsep tentang kehidupan kekal dan surga hanyalah dongeng belaka. Hidup seperti komputer yang akan berhenti bekerja ketika komponennya rusak. Tidak ada kehidupan setelah mati ataupun surga bagi komputer rusak. $^{2}$ Menurut pandangan ini, suatu pengetahuan menjadi bermakna jika pengetahuan bersesuain dengan fakta realitas yang bisa dibuktikan dengan data-data inderawi. ${ }^{3}$ Sedangkan

${ }^{1}$ Muhammad Taqi Misbah Yazdi, Philosophical Instruction: An Introduction to Contemporary Islamic Pilosophy (New York: Global Publication, Binghamton University, 1999 ), h.163.

${ }^{2}$ Pada abad ke-20, kata science terbatas pada metode, konsep, dan ukuran kebenaran yang terbatas pada realitas fisik. Lihat, Stefano Gattei, Thomas Kuhn's "Lingustic Turn" and The Legacy of Logical Empiricism: Incomensurability, Rationality and the Search for Truth (England: Ahsgate Publishing Company, 2008), h. ix.

${ }^{3}$ Lihat, Stephen Hawking, "There is no Heaven: It's A Fairy Story," The Guardian Senin: 18 Mei 2011, http://www.guardian.co.uk/ science/2011/may/15/stephen-hawking-interviewthere-is-no-heaven, (diakses, Rabu, 18 Mei 2011), dan F. Budi Hardiman, Filsafat Modern: Dari Machiavelli hingg Nietzsche, h. 230. 
pengetahuan-pengetahun lain, seperti pengetahuan agama, pengetahuan metafisik dan pengetahuan moral, tidak bermanfaat, tidak berguna, tidak ril dan tentu tidak ilmiah karena tidak bisa dibuktikan dengan data-data inderawi

Sains, menurut cara pandang modern, didefinisikan sebagai sebuah cabang studi yang hanya konsern dengan observasi dan klasifikasi fakta. Para saintis mengetahui bahwa bidang penelitian mereka tidak lain hanyalah berkaitan dengan fenomena yang terukur, sebuah estimasi yang dianggap paling mendekati kebenaran; kebenaran yang berdasarkan pada nilai rata-rata statistik. Oleh karena itulah, seperti yang dikatakan oleh Betran Russel "Physics is mathematical, not because we know so much about the physical world, but because we know so little: it is only its mathematical properties that we can discover." 4

Pandangan sains di atas sangat berbeda dengan pandangan ilmuwan Muslim seperti al-Farabi dan juga Ikhwan al-Shafa. Menurut kedua ilmuan Muslim ini, sains tidak hanya berkaitan dengan objek-objek fisik tetapi meliputi seluruh realitas, baik yang fisik maupun non-fisik, baik etik maupun matematik, baik logika maupun agama. Oleh karena itulah, menurut keduanya, tidak mungkin ada pertentangan antara ilmu agama dan ilmu fisika atau sains, karena ilmu-ilmu tersebut memiliki sumber dan asal yang satu, yaitu Tuhan. Berikut penjelasan tentang pemikiran al-Farabi dan Ikhwan al-Shafa terkait dengan relasi harmonis antara sains dan agama.

\section{Seketsa Biografis Al-Farabi dan Ikhwan al-Shafa}

Dalam studi filsafat Islam, secara historis, sudah jamak diketahui bahwa filosof Muslim pertama biasanya disandarkan kepada Abu Ya'qub al-Kindi (w. 866 M), yang memiliki pengetahuan yang sangat luas sebagaimana tergambar di dalam karya-karyanya yang meliputi

${ }^{4}$ Betran Russel, An Outline of Philosophy, (London and New York: Routladge Classic, 2009), h.171. 
semua bidang keilmuan dari astronomi hingga psikologi, fisika hingga metafisika. Namun demikian, di tangan al-Farabi-lah formulasi, konsep, teori dan kurikulum pendidikan sains dan ilmu agama disajikan secara sistematis dan integratif. ${ }^{5}$ Ia mengembangkan dan mengelaborasi skema dan struktur sains berdasarkan pada pemikiran filosof Yunani dan juga tradisi neo-Platonis yang kemudian dipadukan dengan ilmu-ilmu agama yang berlandaskan pada al-Quran dan hadis nabi Muhammad Saw.

Al-Farabi lahir di Faryab, Khorasan dan saat ini terletak di Afganistan pada tahun 871 dan meninggal sekitar tahun 951 Masehi. Nama lengkapnya adalah Abu Nașr Muhammad ibn Muhammad AlFarabi dan di Barat dikenal dengan sebutan Alpharabius. Karyakaryanya meliputi berbagai bidang ilmu seperti metafisika, kosmologi, psikologi, astronomi, politik, etika, ekonomi, eskatologi, musik, dan juga logika. Salah satu karya yang dapat dijadikan rujukan dalam hubungan harmonis antara sains dan agama adalah Ihsa' al-'Ulum dan Mabadi Ara Ahl am-Madinah al-Fadhilah. Selain itu, karya lain al-Farabi yang juga terkait dengan tema tulisan ini adalah Kitab al-Jam'a Bayna Ra'yay al-Hakimain.

Kontirbusi al-Farabi dalam bidang fisika, metafisika, politik, dan juga logika, telah menempatkannya sebagai filosof Muslim yang sangat unggul dan telah memberikan pengaruh besar terhadap ilmuan setelahnya. ${ }^{6}$ Al-Farabi adalah filosof Muslim pertama yang menulis karya tentang politik yang diinspirasikan oleh karya Republik Plato.7 Ia juga adalah logikawan fenomenal dalam Islam

${ }^{5} \mathrm{Al}$-Farabi disebut sebagai salah satu the universal figures of Islamic sciences. Lihat, Seyyed Hossein Nasr, Sciences and Civilization in Islam (Cambridge: Harvard University Press, 1969), h. 41 dan Sebastian Gunther, "Be Masters in That You Teach and Continue to Learn: Medieval Muslim Tinkers on Educational Theory," Comparative Education Review, Vol. 50, No. 3 (Agustus, 2006), 367,http://www.jstror.org/page/info/about/policies/terms.jsp (diakses, 18 Juni 2012).

${ }^{6}$ Nama-nama seperti ibn Sina, ibn Rushd, ibn Bajjah, dan ibn Tufayl merupakan filosof yang dipengaruhi oleh al-Farabi. Menurut Joshua Parens, para ilmuan di Barat mengenal Plato dan Aristoteles karena jasa-jasa mereka. Lihat, Joshua Parens, An Islamic Philosophy of Vistuous Religions: Introducing al-Farabi (New York: Satae University of New York Press, 2006), h. 4-5

${ }^{7}$ Charles E. Butterworth menyebut sebagai the founder of Islamic Political philosophy. Lihat, Charles E. Butterworth, Al-Farabi the Political Writings: Selected Aphorisms and Other Texts (Ichata dan London: Cornell University Press, 2001), h.x. 
dan telah mengomentari seluruh korpus logika Aristoteles yang dikenal dengan Organon. Al-Farabi secara umum dianggap sebagai pendiri dan salah satu representasi terkemuka dari salah satu aliran filsafat dalam Islam, yaitu aliran peripatetik. Karena kontribusinya tersebut ia disebut sebagai guru kedua setelah Aritoteles. ${ }^{8}$

Sementara itu, Ikhwan al-Shafa adalah satu kelompok ilmuan rahasia yang terdiri dari para saintis dan filosof Muslim dan mendedikasikan hidupnya untuk mengembangkan ilmu pengetahuan. Disebutkan bahwa kelompok tersebut berpusat di Basra, Irak -yang saat itu merupakan ibukota Kekhalifahan Abassiyah- sekitar abad ke-10 Masehi. Ajaran dan filosofis mereka dijelaskan secara terperinci dalam Ensiklopedia Ikhwan Al-Shafa' (Bahasa Arab: Rasa'il Ikhwan al-Shafa'), sebuah ikhtisar dari 52 risalah, yang nantinya akan mempengaruhi ensiklopedia-ensiklopedia lain seperti Ibn Sina. Banyak cendekiawan Barat dan Islam yang meneliti dan menulis identitas dari anggota persaudaraan ini.

Ikhwan al-Shafa selalu berbicara nilai-nilai filsafat sebagai cara untuk mendapatkan Kebenaran dan keinginan mereka untuk selalu mengintegrasikannya dengan hukum Tuhan (namus) yang dibawa oleh para nabi. Ia memberikan konotosi terhadap kata filsafat dengan sebutan hikmah, yang berbeda dengan cara para rasionalis, yang secara silogistik artinya diberikan oleh Aristoteles.

Ikhwan al-Shafa merujuk sumber-sumber ilmu mereka kepada empat macam buku. Pertama, buku-buku matematika dan ilmu pengetahuan alam yang disusun berdasarkan ucapan para filsuf. Kedua, kitab-kitab yang diturunkan, seperti Taurat, Injil, Alquran, dan suhuf para nabi. Ketiga, buku-buku ilmu pengetahuan alam yang membahas bentuk-bentuk berbagai wujud-wujud yang ada sekarang, seperti susunan orbit-orbit, ragam rasi bintang, gerakan dan ukuran planet-planet, jenis-jenis hewan, tumbuhan dan barang tambang, serta berbagai buatan tangan manusia, yang penampakan lahirnya

\footnotetext{
${ }^{8}$ Seyyed Hossein Nasr, The Islamic Intellectual Tradition in Persia, (Richmond Surrey: Curzon Press, 1996), h.59-65.
} 
dilihat tetapi makna batinnnya tidak diketahui banyak orang. Keempat, buku-buku metafisika yang tidak tersentuh kecuali oleh orang-orang yang disucikan dan para malaikat. Ini adalah substansisubstansi, jenis-jenis, macam-macam, dan bagian-bagian jiwa serta perubahan-perubahannya terhadap tubuh, di samping hal-hal- yang terjadi pada jiwa, seperti kemerosotan, kenaikan, kebangkitan dan hisab, surga atau neraka, atau persinggahan di alam barzakh dan wukuf di Padang Arafah. Sebagian besar diskusi mereka ketika berkumpul adalah tentang ilmu jiwa, rasa dan objek rasa, serta akal dan objek akal, di samping penalaran rahasia kitab-kitab Ilahi, apa yang diturunkan kepada nabi, dan makna-makna yang dikandung berbagai ketetapan syariat. Mereka juga mendiskusikan bilangan, ilmu ukur, penghimpunan, dan perbintangan.

\section{Makna Sains Menurut al-Farabi dan Ikhwan al-Shafa}

Di Barat, sejak era modern, kata sains hanya memiliki makna yang berkaitan dengan realitas fisik, seperti fisika, kimia, dan biologi dengan menggunakan metode empiris dan eksperimen yang kemudian dikenal dengan metode ilmiah, di luar lingkup definisi dan metode tersebut tidak disebut sains. Menurut John Walbridge, perubahan utama dari tradisi sains Aristoteles ke tradisi sains modern, menurut John Walbridge, adalah meningkatnya dan penghargaan yang luar biasa terhadap penggunaan metode empiris dan eksperimen, serta penggunaan matematika dalam menghitung, menjumlah dan mengukur fakta-fakta. Apapun yang tidak dapat dijelaskan dengan metode-metode tersebut dapat dikatakan sebagai sesuatu yang tidak diketahui, tidak penting, dan tidak bermakna. "Whatever could not explained by the methods of empirical and mathematical natural philosophy came to be seen as unknowable, unimportant, or nonsensical, especially once the practical science and its method." 9

\footnotetext{
${ }^{9}$ Lihat, John Walbridge, God and Logic in Islam: The Caliphate of Reason, (New York: Cambridge University Press, 2011), h. 22.
} 
Berbeda dengan pengertian sains seperti yang dipahami oleh Barat, menurut al-Farabi, kata sains atau ilmu ('ilm, science) dapat disandarkan kepada berbagai macam objek, seperti ilmu metafisika ('ilm al-Ilahi), ilmu matematika ('ilm al-ta'alim atau 'ilm al-riyadiyah), ilmu fisika ('ilm al-tabi'iyyat), ilmu politik ('ilm al-madani), ilmu etika ('ilm al-akhlaq), dan objek-objek yang lain. Dalam kitabnya Fusul Muntaza'ah, ${ }^{10}$ al-Farabi menyebutkan bahwa ilmu (science) pada dasarnya adalah bagian dari keutamaan pengetahuan reflektif (alnazari) ${ }^{11}$ yang terdapat pada jiwa, ${ }^{12}$ dan melalui jiwa itulah kepastian (certainty) adanya entitas wujud dapat diperoleh,13 bukan hasil buatan dan usaha manusia. Dengan sains seperti ini seseorang dapat menentukan apa saja bagian-bagiannya dan bagaimana cara untuk menentukan entitas-entitas tersebut benar secara pasti, universal, dan memiliki premis-premis primer yang dapat diketahui dan digambarkan oleh akal secara pasti. ${ }^{14}$

Demikian juga, dalam kitabnya, Tahsil al-Sa'sadah, ${ }^{15}$ ketika menjelaskan tentang keutamaan pengetahuan teoritis (al-fada'il al-

\footnotetext{
${ }^{10} \mathrm{Kitab}$ ini sudah diterjemahkan ke dalam bahasa Inggris, Selected Aphorisms. Lihat, Charles E. Butterworth, Al-Farabi the Political Writings: Selected Aphorisms and Other Texts (Ithaca dan London: Cornell University Press, 2001), h. 3-67.

${ }^{11}$ Di kitab yang lain, On The Intellect, al-Farabi menyebutkan bahwa ketika Aristotels menggunakan kata "intellect" di dalam buku Posteriory Analitica, ia maksudkan sebagai kekuatan dan kemampuan jiwa dalam arti bahwa manusia dapat memperoleh premis universal, benar dan niscaya. Dalam konteks ini, manusia dalam memperoleh premis-premis bukan sama sekali hasil dari silogisme atau dari pemikiran-pemikiran diskursif, tetapi didapatkan melalui disposisi secara natural, alami, atau pengetahuan yang tidak disadari darimana asalnya. Lihat, AlFarabi, "The Aim of Aristotle Metaphysics," di dalam John McGinnis dan David C. Resman, penj., Classical Arabic Philosophy: An Anthology of Sources, (Indianapolis: Hacket Publishing Company, Inc., 2007), h.70.

${ }^{12}$ Ikhwan al-Safa' menjelaskan bahwa ilmu adalah bentuk pengetahuan di dalam jiwa atau gambaran objek di dalam jiwa subjek, "surah al-malum fi al-nafs al-'alim.." lihat, Ikhwan alSafa', Rasa'il Ikhwan al-Safa' wa Khullan al-Wafa', jil.1 (Beirut: al-Dar al-Islamiyah, 1992),h. 262.

${ }^{13}$ Ikhwan al-Safa' menyebutkan bahwa jiwa dapat mencerap bentuk-bentuk pengetahuan melalui tiga jalan, salah satunya adalah melalui indera, yang lain adalah melalu pembuktian demonstratif, dan yang terakhir adalah melalui penalaran dan perenungan. Lihat, Ikhwan al-Safa', Rasa'il Ikhwan al-Safa' wa Khullan al-Wafa', jil. 1, h.277.

${ }^{14} \mathrm{Al}-\mathrm{Farabi}$, Fusul Muntaza'ah, www.al-mostafa.com, 2010, 13; Charles E. Butterworth, AlFarabi the Political Writings: Selected Aphorisms and Other Texts, 29; dan Majid Fakhry, AlFarabi: Founder of Islamic Neoplatonism (Oxford: Oneworld Publication, 2002),h. 66

${ }^{15} \mathrm{Kitab}$ ini sudah diterjemahkan dalam bahasa Inggris, The Attainment of Happiness, oleh Muhsin Mahdi. Lihat, Muhsin Mahdi, Alfarabi's Philosophy of Plato dan Aristotle (Amerika Srikat: The Free Press of Glencoe, 1962), h. 13-52.
} 
nazariyah) al-Farabi menyebutkan bahwa sains atau ilmu adalah pengetahun yang memiliki tujuan utama untuk menjadikan semua realitas (al-mawjudat) dapat dimengerti secara jelas (mutayaqqinan). Ilmu ini diperoleh dan dimiliki manusia sejak awal tanpa dirasakan dan tidak diketahui dari mana dan bagaimana cara memperolehnya. ${ }^{16}$ Pengetahuan semacam ini, menurut al-Farabi, adalah pengetahuan pertama (al-'ulum al-awwal). Pengetahuan ini masuk kepada bagian dari pengetahuan teoritis dan marupakan salah satu bagian yang harus dimiliki oleh setiap manusia dan masyarakat jika ingin memperoleh kebahagiaan di dunia maupun setelahnya. Menurut al-Farabi, ada empat kemampuan yang harus dimiliki oleh setiap manusia dan masyarakat jika ingin memperoleh kebahagiaan di dunia dan kehidupan setelahnya, yaitu pengetahuan teoritis (theoritical virtues), kemampuan intellektual (deliberative virtues), akhlak (moral virtues), dan kemampuan praktis (practical art). ${ }^{17}$

Karakteristik utama sains ini adalah adanya kemestian dan kebenaran mengenai wujud secara universal dan tidak mungkin tidak ada. ${ }^{18}$ Menurut istilah Ikhwan al-Safa', ilmu adalah konsepsi tentang wujud berdasarkan pada hakikat dan kebenaran wujud. ${ }^{19}$ Ilmu ini berhubungan dengan wujud yang tidak berubah-rubah. Artinya, jika ada wujud yang berubah, misalnya hari ini ada di suatu tempat dan besok berpindah ke tempat yang lain atau sekarang benar dan besok salah, maka objek atau wujud seperti itu tidak termasuk pada bagian dari sains hakiki atau sains sejati.

Terkait dengan pengetahun non-sejati, al-Farabi memberikan contoh sebagai berikut; kita tahu bahwa hari ini ada seseorang

\footnotetext{
${ }^{16}$ Al-Farabi, Kitab Tahsil al-Sa'adah (Beirut: Dar wa Maktabah al-Hilal, 1995), 26 dan Muhsin Mahdi, Alfarabi's Philosophy of Plato and Aristotle, 1.

${ }^{17}$ Lihat, Al-Farabi, Kitab Tahsîl al-Sa'adah, 25; Muhsin Mahdi, Alfarabi's Philosophy of Plato and Aristotle, 1; dan Miriam Galston, "The Theoretical and Practical Dimension of Happiness as Portrayed in the Political Treatese of al-Farabi, di dalam Charles E. Butterworth, ed., The Political Aspect of Islamic philosophy, (Massachusetts: Harvard University Press, 1992), h. 114 .

${ }^{18} \mathrm{Al}-F a r a b i$, Fusul Muntaza'ah, h.13.

${ }^{19}$ Ikhwan al-Safa', Rasa'il Ikhwan al-Safa' wa Khullan al-Wafa', jil. 3 (Qum: Maktab alA'lam al-Islami), 2000),h. 283.
} 
sedang duduk di suatu tempat yang mana duduknya tersebut hanyalah sementara dan ada kemungkinan besok atau setelah duduk ia akan berdiri. Nah, pengetahuan yang semacam ini tidak disebut pengetahun sejati, alasannya adalah karena pengetahuan tersebut terkait dengan wujud yang berubah-rubah. Adapun pengetahuan sejati, al-Farabi mecontohkan pengetahuan mengenai angka tiga adalah ganjil dan angka empat adalah genap. Ganjilnya angka tiga tidak akan dapat berubah karena disebabkan oleh berbagai hal, demikian juga genapnya angka empat. ${ }^{20}$

Kehakikian dan kesejatian sains ini terletak pada universalitasnya. Oleh karena itu, al-Farabi menyebut sains ini dengan istilah sains universal, ${ }^{21}$ dan penyebutan ini untuk membedakan dengan sains partikular. Ilmu ini salah satunya adalah menyelidiki sesuatu yang bersifat umum untuk semua makhluk seperti keberadaan dan kesatuannya, spesiesnya, akibat aksidenaksidennya; aksiden yang tidak spesifik untuk satu subjek dari ilmu tertentu seperti keutamaan, potensi, aktualitas, kesempurnaan, ketidaksempurnaan, dan aksiden-aksiden yang serupa; dan akhirnya menyelidiki tentang prinsip umum untuk segala sesuatu yang eksis, yaitu Tuhan.

Menurut al-Farabi, hanya ada satu sains universal, dan jika ada dua sains universal maka salah satunya memiliki subjek spesifik. Apabila sebuah sains sudah memiliki subjek spesifik, maka sains tersebut disebut sains pertikular. Sains partikular adalah ilmu yang memiliki subjek dan objek tertentu melalui fakultas estimasi (estimative faculty) dan objek penelitian sains ini adalah khususnya berkaitan dengan objek-objek yang memiliki aksiden-aksiden, misalnya, ilmu pengetahuan alam menyelidiki tentang eksistensi,

\footnotetext{
${ }^{20}$ Lihat, Al-Farabi, Fusul Muntaza'ah, 13.

${ }^{21}$ Lihat, John McGinnis dan David C. Resman, pen., Classical Arabic Philosophy: An Anthology of Sources (Indianapolis: Hacket Publishing Company, Inc., 2007), h.79.
} 
yaitu benda, baik dari segi gerak, perubahan, dan diamnya atau dari segi sebab dan akibat yang dihasilkan darinya. ${ }^{22}$

Selain adanya kemestian dan kebenaran yang pasti, sains seperti itu juga disebut sebagai sains sempurna (the perfect science). Kesempurnaan ini didasarkan pada kognisi-kognisi tertentu yang inheren di dalam diri manusia secara alami. Al-Farabi menjelaskan, "once he attains certainty about what he was investigating, this is the perfect science of what he wants to know." 23

Secara umum, al-Farabi membagi sains pada dua bagian; teoritis dan praktis. ${ }^{24}$ Sains teoritis adalah pengetahuan manusia tentang suatu realitas atau wujud yang mana manusia tidak dapat merubah dan memindahkan wujud tersebut. Sebaliknya, sains praktis adalah pengetahuan yang dengannya manusia dapat membedakan realitas dan dapat merubah serta memindahkannya. ${ }^{25}$

Sesuai dengan definisi sains itu sendiri yaitu mengetahui segala sesuatu sebagaimana mestinya, maka objek sains teoritis adalah semua realitas. Adapun objek kajian sains praktis adalah tindakantindakan manusia. Pembagian sains pada teoritis dan praktis sejalan dengan pembagian potensi akal yang dimiliki manusia, yaitu akal teoritis dan akal praktis, ${ }^{26}$ dan juga macam-macam realitas wujud yang menjadi objek pengetahuan.

Al-Farabi telah menulis karya khusus -semacam kurikulumtentang struktur sains atau ilmu-ilmu dalam kitabnya Ihsa' al-'Ulum the enumeration of sciences. ${ }^{27}$ Kitab ini sudah diterjemahkan ke dalam bahasa Prancis, Enumération des Sciences ou Classification des Sciences, dan dalam bahasa Inggris, The Enumeration of Sciences. Terkait dengan

22. Lihat, John McGinnis dan David C. Resman, pen., Classical Arabic Philosophy: An Anthology of Sources, h.78

${ }^{23}$ Muhsin Mahdi, Alfarabi's Philosophy of Plato and Aristotle, h.74

${ }^{24}$ Muhsin Mahdi, Alfarabi's Philosophy of Plato and Aristotle,h. 72-73.

${ }^{25} \mathrm{Al}-\mathrm{Farabi}$, Fusul Muntaza'ah, 13 dan Charles E. Butterworth, Alfarabi, The Political Writing: Selected Aphorisms and other Texts,

${ }^{26}$ Charles E. Butterworth, Alfarabi, The Political Writing: Selected Aphorisms and other Texts, h.28.

${ }^{27}$ Lihat, Ilham Mansoor, Enumération des Sciences ou Classification des Sciences (Libanon: Markaz al-Anma' al-Qumi, 1991) dan Majid Fakhry, A History of Islamic Philosophy, h.112. 
kitab ini, Majid Fakhry berkomentar bahwa pemikiran al-Farabi mengenai klasifikasi mungkin adalah hal yang paling penting untuk memahami konsep dan pemikiran filsafat al-Farabi kaitannya dengan ilmu-ilmu lain, karena klasifikasi tersebut dapat memahami seluruh konsepsi filsafat Islam dan hubungannya dengan silabus ilmu-ilmu Yunani dan ilmu-ilmu Islam.

Demikian juga Ikhwan al-Safa', dalam risalah ke-7, telah menulis salah satu pasal tentang jenis-jenis ilmu. ${ }^{28}$ Kedua ilmuan tersebut mencoba untuk menyampaikan ilmu-ilmu apa saja yang perlu dipelajari, ilmu yang lebih dulu dan penting untuk diketahui dan dipahami, serta bagaimana hubungan antara satu ilmu dengan ilmuilmu yang lain. Ikhwan al-Safa'mengatakan bahwa jenis-jenis ilmu tersebut adalah sebagai petunjuk bagi para penuntut ilmu dan supaya mereka mendapatkan petunjuk terhadap tujuan yang diharapkannya, "liyakuna dalilan litalib al-ilm ila ighradihim wa liyahtadu ila matlubatihim." 29

Struktur sains yang ditulis al-Farabi dan Ikhwan al-Safa' didasarkan pada informasi atau ilmu-ilmu yang sedang berkembang dan dipelajari pada masanya, baik ilmu yang berasal dari tradisi yang sudah berkembang di mana al-Farabi hidup seperti ilmu bahasa Arab dilihat dari aspek gramatikal, bacaan, sastranya; ilmu-ilmu agama seperti tafsir, teologi, fikih, dan tasawuf; maupun dari informasi atau ilmu yang datang dari luar Arab seperti aritmatika, geometri, astronomi, musik, fisika, kedokteran, logika, dan filsafat. Secara umum, al-Farabi meringkasnya menjadi tujuh cabang ilmu dengan struktur sebagai berikut; ilmu bahasa, logika, matematika, fisika, metafisika, politik, dan syariah (agama). ${ }^{30}$

Sedangkan Ikhwan al-Safa' mengklasifikasikan menjadi tiga bagian utama; ilmu pendahuluan atau keterampilan (al-riyadiyah), dan ilmu agama (al-shar'iyyah al-wad'iyyah), filsafat (al-falsafiyah al-

\footnotetext{
${ }^{28}$ Ikhwan al-Safa', Rasa'il Ikhwan al-Safa' wa Khullan al-Wafa', jil. 1, h. 266.

${ }^{29}$ lihat, Ikhwan al-Safa', Rasa'il Ikhwan al-Safa' wa Khullan al-Wafa', jil. 1, h.266.

${ }^{30} \mathrm{Al}-\mathrm{Farabi}$, Ihsa' al-'Ulum (Beirut: Dar wa Maktabah al-Hilal, 1996), h.15.
} 
haqiqah). ${ }^{31}$ Secara esensial, antara Ikhwan al-Safa' dan al-Farabi dalam mengklasifikan ilmu adalah sama. Bahkan, Ikhwan al-Safa' dalam menjelaskan macam-macam ilmu lebih banyak dan lebih terperinci dibandingkan al-Farabi terutama dalam ilmu agama atau syariah. Ia menyebutkan bahwa ilmu agama ada enam macam; pertama adalah ilmu turunnya ayat (al-tanzil). Kedua adalah hermeneutika (al-ta'wil). Ketiga adalah ilmu riwayat dan khabar. Kempat adalah ilmu fikih, sunnah dan hukum-hukum. Kelima adalah ilmu nasehat, zuhud dan tasawwuf. Keenam adalah ilmu ta'wil mimpi.

\section{Hubunngan Sains dan Agama}

Secara umum, baik al-Farabi maupun Ikhwan al-Shafa menolak dikotomi atau disintegrasi sains dan agama (ilmu agama). Alasannya karena jika ada dikotomi -antara ilmu agama dan sains- akan menggugurkan argumentasi dan kebenaran yang menyebutkan bahwa semua sumber dan asal ilmu pengetahuan berasal Yang Esa, Yang Tunggal, dari al-'Alim, yaitu Tuhan yang Maha Esa. Prinsip inilah yang dikenal dengan paradigma Tauhid, suatu cara pandang yang menyebutkan bahwa segala sesuatu berasal dari-Nya, baik objek fisik maupun non-fisik, baik ilmu agama maupun ilmu fisika.

Menurut al-Farabi, antara kredo atau keimanan (millah) dan agama (din) tidak ada perbedaan, karena keduanya adalah sinonim. Demikian juga tidak ada perbedaan antara syariah (al-shari'ah) dan tradisi (al-sunnah), keduanya adalah satu. Bahkan, al-Farabi menegaskan bahwa menurut pendapat mayoritas ulama kedua aspek terakhir -syariah dan sunnah- memiliki peran signifikan dalam menentukan dan mengaplikasikan gagasan atau pendapat untuk menjadi hukum. Oleh karena itu, kredo atau keimanan (millah), agama (din), dan syariah (al-shari'ah) merupakan istilah yang berbeda tetapi memiliki makna yang sama. ${ }^{32}$

\footnotetext{
${ }^{31}$ Ikhwan al-Safa', Rasa'il Ikhwan al-Safa' wa Khullan al-Wafa', jil. 1, h. 267.

${ }^{32} \mathrm{Al}-\mathrm{Farabi}$, "Kitab al-Millah," dalam Mu\}sin Mahdi, al-Millah wa-Nususun Ukhrá (Beirut: Dar al-Mashriq, 1991). h. 46.
} 
Al-Farabi menyebutkan bahwa keutamaan ilmu tergantung dari tiga aspek; karena objeknya, bukti-bukti yang mendalam, dan karena kegunaannya. Keutamaan Ilmu syariah karena aspek ketiga, yaitu karena kegunaannya pada suatu kaum dan waktu tertentu, baik saat ini maupun di masa yang akan datang. Menurut Seyyed Hossein Nasr, Syariah [hukum Islam] adalah seperti keliling lingkaran, setiap titik yang mewakili seorang Muslim yang berdiri pada lingkaran itu. Setiap jari-jari yang menghubungkan setiap titik keliling kepada pusat melambangkan tarekat, dan titik pusat adalah hakikat. Seluruh lingkaran, dengan pusat, lingkaran, dan jari-jari, dapat dikatakan mewakili totalitas dari tradisi Islam. ${ }^{33}$

Agama yang dimaksud al-Farabi memiliki dua dimensi; konsep dan tindakan (ara wa-af'al). Pembagian agama dalam dua bagian, konsep dan tindakan, selaras dengan pembagian sains (filsafat) yaitu teoritis dan praktis. ${ }^{34}$ Baik al-Farabi maupun Ikhwan al-Shafa' menempatkan sains, yang dalam pengertian modern yang terbatas pada ilmu fisik atau empris seperti fisika, biologi, kimia, dan matematika, berada dalam kerangkat umum ilmu rasional atau filsafat. Ilmu-ilmu tersebut disebut ilmu teoritis yang dibedakan dengan ilmu-ilmu praktis seperti etika, ekonomi, dan politik. ${ }^{35} \mathrm{Ilmu}$ teoritis dan praktis dalam konteks ini berada dalam kerangka filsafat atau ilmu rasional, 'aqliyyah. Sementara itu, ilmu agama disebut naqliyyah. ${ }^{36}$

Aspek teoritis atau ide-ide (ara) dalam agama, menurut al-Farabi, terdari dari dua macam; teoritis (nazariyyah) dan ikhtiari (iradiyyah) atau aplikatif. Pokok persoalan yang dibicarakan dalam ruang lingkup pendapat teoritis (nazariyyah) terdiri dari lima bagian;37

${ }^{33}$ lihat, Al-Farabi, "Fi Ma Yasihhu wa ma la Yasihhu min Ahkam al-Nujum," di dalam Ja 'far Ali Yasin, Risalatani Falsafiyyatani, (Beirut: Dar al-Manahil, 1987), 48 dan Seyyed Hossein Nasr, Seyyed Hossein Nasr, Islam: Religion, History, and Civilization (New York: HarperCollins, 2003), h. 76.

${ }^{34}$ Muhsin Mahdi, al-Millah wa-Nususun Ukhrá, h. 43

${ }^{35}$ Ikhwan al-Shafa', Rasa'il Ikhwan al-Shafa', jil. 1, h. 267-272

${ }^{36}$ Penyebutan sains dalam tulisan ini adalah satu tarikan dengan kata filsafat. Oleh karena itu, kata sains dan filsafat digunakan secara bergantian atau secara bersama-sama.

${ }^{37}$ Muhsin Mahdi, al-Millah wa-Nususun Ukhrá, h. 44-45. 
Pertama adalah mengenai wujud Tuhan dan dunia spiritual (alruhaniyyun), tingkatannya dalam dirinya, relasinya dengan Tuhan, dan masing-masing tugasnya. Kedua, berkaitan dengan alam; bagian dan tingkatan-tingkatan alam; bagaimana benda-benda primer dapat terjadi dan menjadi sumber atau menjadi sebab bagi yang lain serta proses kejadian dan proses kehancurannya; bagaimana hubungan antara satu benda dengan benda yang lain dan dapat terorganisir sedemikian rupa serta berjalan secara adil; bagaimana relasi masingmasing benda tersebut dengan Tuhan dan dengan dunia-dunia spiritual.

Pokok persoalan ketiga dari ide-ide teoritis adalah berkaitan dengan eksistensi manusia dan jiwanya, manusia dan akalnya, serta keberadaannya di alam semesta dan relasinya dengan Tuhan. Pokok persoalan keempat adalah kenabian (nubuwwah) dan wahyu, misalnya apakah wahyu dan bagaimana proses turunnya. Pokok persoalan kelima adalah berkaitan dengan eskatologi, yaitu kematian dan kehidupan di akhirat, dan kebahagiaan tertinggi dan kesengsaraan yang dapat diperoleh oleh manusia di kehidupan setelah mati.

Sementara itu, pokok persoalan dalam pendapat ikhtiari (iradiyyah) adalah berkaitan dengan para nabi (anbiya'), raja-raja utama, pemerintahan yang saleh, dan para pemimpin yang berada di jalan yang benar dan telah sukses di masa lalu. Di samping itu, dibicarakan juga tentang hal-hal umum yang berkaitan dengan mereka seperti tindakan-tindakan baik, jiwanya dan jiwa-jiwa pengikutnya dan dampaknya pada masyarakat baik di satu kota maupun dalam sebuah negara. Jika di dalam pendapat ikhtiari ini dijelaskan tentang para pamimpin utama, saleh, dan bertindak benar, demikian juga sebaliknya, yaitu diceritakan tentang raja-raja bejat dan pemerintahan boros yang menggunakan otoritasnya sehingga masyarakat menjadi terbelakang, para pemimpin sesat dan berada di jalan yang sesat. ${ }^{38}$

\footnotetext{
${ }^{38}$ Muhsin Mahdi, al-Millah wa-Nususun Ukhrá, h. 45.
} 
Dimensi lain agama adalah dimensi praktis (af al), dimensi etis atau moral. Dimensi ini berkaitan dengan tindakan dan ucapanucapan manusia dalam menyembah dan memuji Tuhan; mengagungkan dunia-dunia spiritual dan malaikat; menghormati raja-raja utama, pemerintahan yang saleh, dan para pemimpin yang benar, serta berada di jalan yang benar dan telah sukses di masa lalu. Demikian juga sebaliknya, yaitu bagaimana cara mengkritisi raja-raja bejat, pemerintahan boros, para pemimpin sesat dan berada di jalan sesat melalui penggunaan otoritasnya sehingga masyarakat menjadi terbelakang. Dalam konteks ini, agama menjelaskan tentang tindakan manusia sehari-hari hubungannya dengan dirinya, sesamanya, dan juga lingkungan dalam kerangka keadilan. ${ }^{39}$

Kebenaran agama yang diyakini oleh manusia, secara umum, diperoleh melalui dua cara; melalui dirinya atau pengetahuan primer ('ilm awwal), dan melalui pengetahuan demonstrasi (burhan). Jika agama yang dianut manusia tidak memiliki keyakinan baik melalui pengetahuan primer atau melalui pengetahuan demonstrasi, maka agama tersebut disebut agama sesat (millah dalalah)..$^{40}$

Di dalam kitab al-Tahsil al-Sa'adah, al-Farabi menyebutkan bahwa cara untuk memperoleh kebenaran melalui dua cara; melalui demonstrasi yang pasti (al-burhan al-yaqin) dan penerimaan (al-iqna'). Al-Farabi mencontohkan dari kedua cara tersebut sebagai berikut; pertama, ketika seseorang memperoleh pengetahuan mengenai wujud-wujud melalui pengajaran dan melalui akalnya, dan selanjutnya pengetahuan tersebut selanjutnya dibuktikan secara demonstratif. Pengetahuan yang diperoleh berdasarkan pada proses tersebut disebut pengetahuan filsafat. Kedua, ketika seseorang mengetahui wujud-wujud dengan cara menghayalkan wujud-wujud tersebut melalui tanda atau perumpamaan-perumpamaannya dan dibuktikan dengan metode persuasif atau penerimaan (al-iqna'). Al-

\footnotetext{
${ }^{39}$ Muhsin Mahdi, al-Millah wa-Nususun Ukhrá, h. 46.

${ }^{40}$ Muhsin Mahdi, al-Millah wa-Nususun Ukhrá, h. 46.
} 
Farabi menyebut pengetahuan yang diperoleh berdasarkan pada proses tersebut disebut pengetahuan agama. ${ }^{41}$

Argumen yang disampaikan bahwa filsafat menjelaskan segala sesuatu berdasarkan pada konsepsi dan persepsi intelek (máqulan aw mutas\}awwiran), sedangkan agama berdasarkan imajinasi (mutakhayyilan). Filsafat membuktikan dengan demonstrasi, sedangkan agama mengamalkan dengan suka rela. Ikhwan al-Safa' menjelaskan bahwa ilmu filsafat dan al-syari'ah al-nubuwiyyah (agama), merupkan dua aspek Ketuhanan yang secara fundamental (usul) berkesesuaian dalam tujuan dan hanya berbeda dalam hal furu' (cabang), karena tujuan tertinggi dari filsafat adalah Tuhan. Tujuan filsafat dalam memikirkan ilmu-ilmu matematika adalah jalan dan langkah menuju ilmu-ilmu fisika. Adapun tujuan dalam memikirkan ilmu-ilmu fisika adalah untuk naik dan bergerak ke atas menuju ilmu-ilmu Ilahi yang merupakan puncak tujuan ahli hikmah dan batas akhir yang digapai dengan pengetahuan-pengetahuan hakiki. ${ }^{42}$

Jika filsafat menjelaskan substansi asal pertama dan wujud non fisik melalui akal, maka agama mengimajinasikannya melalui prinsip-prinsip yang ada dalam benda-benda fisik seperti struktur dalam masyarakat atau kota, menyamakan tindakan Tuhan (tashbih) dengan fungsi pemimpin di dalam masyarakat, dan menyerupakan objek-objek akal dengan objek-objek inderawi. ${ }^{43}$

Secara eksplisit al-Farabi dan Ikhwan al-Shafa menunjukkan bahwa pengetahuan filsafat, sains dan agama adalah berbeda, tetapi perbedaan tersebut terbatas hanya pada proses dan metode dalam memperoleh pengetahuan. Adapun pada subjek dan objek pengetahuan dari kedua ilmu filsafat dan agama adalah sama, "fa-almillah muhakiyyah li-al-falsafah...wa-huma yashtamila 'alá mawdu'at bia'yaniha." 44

\footnotetext{
${ }^{41}$ Al-Farabi, Tahsil al-Sa'adah (Beirut, Dar wa Maktabah al-Hilal, 1995), h.88-89.

${ }^{42}$ Ikhwan al-Safa', Rasail Ikhwan al-Safa', jil. 1 (Beirut: al-Dar al-Islamiyyah, 1992), h. 75.

${ }^{43} \mathrm{Al}-\mathrm{Farabi}$, Tahsil al-Sa'cadah, h.89-90.

${ }^{44} \mathrm{Al}-\mathrm{Farabi}$, Tahsil al-Sa'adah, h. 89.
} 
Antara sains dan ilmu agama sama-sama memberi perhatian kepada perinsip-perinsip tertinggi wujud (al-mabadi' al-quswa li almawjudat); keduanya mempelajari tentang prinsip dan sebab pertama bagi wujud (al-mabda' al-awwal wa-al-sabab al-awwal); dan keduanya memiliki tujuan yang sama yaitu kebahagiaan tertinggi baik yang berkaitan dengan tujuan hidup manusia maupun bagi wujud-wujud lain. Bahkan, dalam konteks proses dan metode, jika ilmu agama mengadopsi metode filsafat dan sekaligus menggunakan metode persuasi, maka ilmu agama juga akan sampai pada tingkat kebenaran filsafat.

Ilmu rasional atau sains dan agama (al-syarīah al-nubuwiyyah) merupakan dua aspek Ilahiyyah yang berkesesuaian dalam tujuan tertinggi. Mereka hanya berbeda dalam hal cabang (furu'). Tujuan tertinggi dari filsafat adalah menyerupai Tuhan dengan mengenalNya dan melalui tindakan-tindakan baiknya bersama masyarakat, sedangkan agama memberikan petunjuk dan jalan bagaimana cara sampai kepada Tuhan. Sains adalah konsepsi sesuatu berdasarkan pada hakikat dan kebenarannya. Penjelasan ini sesuai makna sains dalam Islam, yaitu ma'rifah al-shai 'ala mahua bihi, pengetahuan sebagaimana adanya. Sedangkan iman atau agama adalah pengakuan dan pembenaran terhadap kebenaran tersebut. Tujuan utama dari wahyu dan nubuwwah adalah dalam rangka melatih, mendidikak, memperbaiki dan menyucikan jiwa manusia dari alam materi. Argumen terakhir inilah yang menjadi tujuan dan maksud dari ilmu-ilmu filsafat dan juga syariah nabawiyyah secara keseluruhan. Ikhwan al-Safa' mengatakan bahwa perbedaan antara keduanya dalam cara-cara untuk mencapainya adalah niscaya, karena kemampuan akan dan jiwa setiap mamusia dalam menangkap kebenaran adalah berbeda-beda. ${ }^{45}$

Oleh karena itu, secara metodologis, cara untuk mengetahui Tuhan menurut al-Farabi dan Ikhwan al-Shafa melalui beberapa cara. Di antaranya adalah dengan mempelajari dan meneliti alam semesta secara mendetail melalui empat prinsip yaitu sebab material, efisien,

\footnotetext{
${ }^{45}$ Ikhwan al-Safa', Rasail Ikhwan al-Safa', jil. 1, h.30.
} 
formal, dan final. Dengan meneliti alam semesta, maka akan tampak dan jelas bahwa alam semesta tidak beridiri sendiri, tetapi ada yang menciptakan. Metode ini dikenal dengan filsafat alam. Cara lain adalah melalui perenungan dan analisa mengenai esensi wujud, misalnya, analisa mengenai pembagian wujud kepada dua bagian; wujud aktual dan wujud potensial. Wujud aktual ada dengan sendirinya, tanpa awal dan tanpa akhir. Ia adalah asal dari segala sesuatu. Tidak ada sebab bagi keberadaannya. Adapun wujud potensial adalah eksistensinya membutuhkan pada sesuatu yang lain.46 Inilah yang dikenal dengan alasan secara mutlak.

\section{Penutup}

Berdasarkan pada penjelasan di atas, tampak jelas bahwa alFarabi dan Ikhwan al-Shafa dengan berbagai argumentasi dan juga bukti-bukti melalui karya-karyanya, menegaskan bahwa antara ilmu agama dan sains atau filsafat tidaklah bertentangan. Baik ilmu agama, naqliyyah, maupun sains, 'aqliyyah, sama-sama memiliki manfaat dalam mengantarkan manusia untuk memperoleh kebahagiaannya yang tertinggi, yaitu menyatu dengan Tuhan.

Bagi al-Farabi dan Ikhwan al-Shafa', mempelajari dunia fisika, sebagaimana menjadi konsern saintis modern, tidak dapat dipisahkan dari dunia di balik fisik itu sendiri atau Dzat yang menciptakan dunia fisik. Pun demikian, dengan mempelajari dunia metafisika, matematika, dan fisika akan berdampak pada kualitas tindakan dan perbuatan sang subjek. Artinya, semakin seseorang memiliki pandangan dan pengetahuan yang integratif antara sains dan ilmu agama, maka tindakan dan perbuatannya akan semakin baik dan berkualitas.

${ }^{46}$ Ibrahim 'Ati, al-Insan fi al-Falsafah al-Islamiyyah: Namudhaj al-Farabi (Alexandrina: alHay'ah al-Misriyyah al-'Amah li-Alkitab: 1993), h. 66, 80-81. 


\section{Pustaka Acuan}

'Ati, Ibrahim. al-Insan fi al-Falsafah al-Islamiyyah: Namudhaj al-Farabi. Alexandrina: al-Hay'ah al-Misriyyah al-'Amah li-Alkitab: 1993.

Butterworth, Charles E. Al-Farabi the Political Writings: Selected Aphorisms and Other Texts. London: Cornell University Press, 2001.

-----------, ed. The Political Aspect of Islamic philosophy. Massachusetts: Harvard University Press, 1992.

Fakhry, Majid. Al-Farabi: Founder of Islamic Neoplatonism. Oxford: Oneworld Publication, 2002.

Al-Farabi. Fusul Muntaza'ah, www.al-mostafa.com, 2010.

--_--_--_Ihsa' al-'Ulum. Beirut: Dar wa Maktabah al-Hilal, 1996.

1995. , Kitab Tahsil al-Sa'adah. Beirut: Dar wa Maktabah al-Hilal, -,Tahsil al-Sa'adah. Beirut, Dar wa Maktabah al-Hilal, 1995.

Gattei, Stefano. Thomas Kuhn's "Lingustic Turn" and The Legacy of Logical Empiricism: Incomensurability, Rationality and the Search for Truth. England: Ahsgate Publishing Company, 2008.

Hardiman, F. Budi. Filsafat Modern: Dari Machiavelli hingg Nietzsche.

Hawking, Stephen. "There is no Heaven: It's A Fairy Story," The Guardian Senin: 18 Mei 2011, http://www.guardian.co.uk/ science/2011/may/15/stephen-hawking-interview-there-is-noheaven, (diakses, Rabu, 18 Mei 2011.

Mahdi, Muhsin. Alfarabi's Philosophy of Plato dan Aristotle.Amerika Srikat: The Free Press of Glencoe, 1962. 1991.

McGinnis, John dan David C. Resman, pen., Classical Arabic Philosophy: An Anthology of Sources. Indianapolis: Hacket Publishing Company, Inc., 2007.

Misbah Yazdi, Muhammad Taqi. Philosophical Instruction: An Introduction to Contemporary Islamic Pilosophy. New York: Global Publication, Binghamton University, 1999.

Nasr, Seyyed Hossein. Sciences and Civilization in Islam. Cambridge: Harvard University Press, 1969. Gunther, Sebastian. “Be 
Masters in That You Teach and Continue to Learn: Medieval Muslim Tinkers on Educational Theory," Comparative Education Review, Vol. 50, No. 3 (Agustus, 2006), 367,http://www.jstror.org/page/info/about/policies/terms.js p (diakses, 18 Juni 2012). HarperCollins, 2003.

------,The Islamic Intelectual Tradition in Persia. Richmond Surrey: Curzon Press, 1996.

al-Shafa', Ikhwan Rasa'il Ikhwan al-Safa' wa Khullan al-Wafa', jil. 3. Qum: Maktab al-A'lam al-Islami, 2000.

--------, Ikhwan. Rasa'il Ikhwan al-Safa' wa Khullan al-Wafa', jil.1. Beirut: al-Dar al-Islamiyah, 1992.

Netton, I. R. Muslim Neopaltonists: An Introduction to the Thought of the Brethren of Purity. Endinburgh: Endinburgh University Press, 1991.

O'Brien, Elmer. The Essential of Plotinus. Indianapolis: Hacket Publishing Company, 1984.

Parens, Joshua. An Islamic Philosophy of Vistuous Religions: Introducing al-Farabi. New York: Satae University of New York Press, 2006.

Russel, Betran. An Outline of Philosophy. London and New York: Routladge Classic, 2009.

Walbridge, John. God and Logic in Islam: The Caliphate of Reason. New York: Cambridge University Press, 2011.

Yasin, Ja'far Ali. Risalatani Falsafiyyatani. Beirut: Dar al-Manahil, 1987 